\title{
Distribution of Body Energy in Etroplus suratensis (Bloch)
}

\author{
S. M. Shivaprakash ${ }^{1}$ and N. Shivashankar ${ }^{2} *$ \\ ${ }^{1}$ Department of Fisheries Resource Management, Karnataka Veterinary and Fisheries \\ Sciences University, College of Fisheries Mangalore 575 002, Karnataka, India \\ ${ }^{2}$ Project Planning and Monitoring Cell, University of Agricultural Sciences Raichur, India \\ *Corresponding author
}

A B S T R A C T

\section{Keywords}

Body energy,

Etroplus suratensis,

Mean energy

density

Article Info

Accepted:

15 December 2019

Available Online:

20January 2020
The present study was carried out to find out the distribution energy pattern in the body parts of Etroplus suratensis (bloch). The study indicated that the mean energy density of the edible portion of immature fish was 17.47 $\mathrm{kJ} / \mathrm{g}$ dry weight compared $20.20 \mathrm{~kJ} / \mathrm{g}$ and $19.65 \mathrm{~kJ} / \mathrm{g}$ of adult female and male respectively. Similarly the energy density of inedible portion of immature fish was $15.65 \mathrm{~kJ} / \mathrm{g}$ while that of adult female and male were $17.49 \mathrm{~kJ} / \mathrm{g}$ and $16.62 \mathrm{~kJ} / \mathrm{gdry}$ weight respectively.

\section{Introduction}

The pearl spot, Etroplus suratensis, is an estuarine fish of commercial importance. It possesses certain requisite qualities essential for aquaculture such as good body weight, growth rate, high adaptability for food, tasty flesh and good market price (Joseph, 1980; Jayaprakash and Phil, 1980; Rattan, 1994). Etroplus suratensisis a widely cultured species in the Indo-pacific region and is known to breed in confined waters (Hora and Pillay, 1962).
Being euryhaline, the species could easily be acclimatized to fresh waters indicating its suitability in pond aquaculture. E. suratensis is also maintained as all aquarium fish because of its attractive colouration (Rattan, 1994). However, the successful culture of any endemic species, Information on feeding habits, digestive physiology, reproductive biology, water quality parameters, proximate analysis of body parts etc. are the prerequisites. Hence the present research was carried out to find out energy distribution in the fish 


\section{Materials and Methods}

\section{Fish sampling site}

The present investigation was carried out in the estuarine area formed by the confluence of Mulki (Shambhavi) and Pavanje rivers and both open into the Arabian sea at a point about $29 \mathrm{KM}$ north of Mangalore in south India $\left(13^{\circ} 05^{\prime} \mathrm{N} ; 7^{\circ} 47^{\prime} \mathrm{E}\right)$. The area has been referred to as Mulki estuary, since the Mulki river is the major water source, while Pavanjeriveris only a tributary. The estuary is flooded with fresh water from the drainage area and the estuarine waters attain almost fresh water conditions during the south-west monsoon season (June to September).

\section{Collection of specimens}

Fresh samples of Etroplus suratensis caught from the estuary as well as fresh fish purchased from landing centre.. A total of 1256 specimens was examined, of which 578 were female, 334 male and 344 were immature. The size range of the fish varied from 5.20 cmto23.50 cm TL. Only live specimens were used for physiological studies.

\section{Energy estimation}

Energy content of the dried samples of the whole body of fish, liver, gonad, muscle, skin, fins, head, visceral organs etc., were measured in different stages of maturity using an autobomb automatic adiabatic bomb calorimeter (Model: Gallenkamp, CBA- 305, UK make). The energy values of the tissue are expressed as $\mathrm{kJ} / \mathrm{g}$ dry matter. Energy values of the whole body of fish belonging to the three stages of maturity namely, immature (Stage I $<10 \mathrm{~cm}$ TL), maturing (Stage II in the size range of 10-15 cm TL) and mature (Stage III,IV, V \& VI with size > $15 \mathrm{~cm}$ TL) were, however, detennined in different months of the year.

\section{Results and Discussion}

Proportion of edible and inedible body parts of E.suratensis and their energy content

The proportion of different body parts of E.suratensis categorized as edible and inedible in immature and mature fish are provided in Table 1. Immature fish as 56.49 $\%$ edible and $43.51 \%$ of inedible parts in their body. However in the mature fish, male exhibited a higher proportion of edible body arts $(61.92 \%)$ compared to female $(53.92 \%)$.

\section{Energy distribution in different body parts of E.suratensis}

The percentage distribution of energy in different body parts of fish are given in Table 2.The percentage of energy distribution of different body parts of fish showed that among immature fish, muscle contributed a maximum of $43.64 \%$ while head and visceral organs shared $24.99 \%$ and $12.10 \%$ respectively. The share of energy by skin was $10.27 \%$ and that of scales was $4.61 \%$. Fins contributed the least energy(4.38\%).Similarly in case of adults also muscle ranked first with female showing $40.59 \%$ and male $50.18 \%$. The second highest energy containing organ was head (female with $31.84 \%$ and male with $24.43 \%$ ) followed by fins in female $(9.3 \%)$ and skin in male (9.66\%). The least energy containing body part in female was scales $(5.00 \%)$ while in male it was visceral organs $(4.11 \%)$.

Proportion of edible and inedible body parts of $E$. suratensis and their energy content

While selecting a species for aquaculture it is desirable to select a species which contains more edible body parts (i.e., after the removal of viscera, fluids, head, scales, fins etc.). Fish 
flesh comprises approximately $60 \%$ of body weight of fish, varying considerably from species to species (Pigott and Tucker, 1990).

In the present study, E.suratensis has been found to possess a high proportion of muscle comparable with those of popular food fishes.As it can be seen from the Table 1 ,immaturefish has muscle comprising $47.62 \%$ and mature male and female with $55.34 \%$ and $47.09 \%$ of the body weight respectively. According to Jobling (1995) gold fish, Carassius auratus possesses 40\%, salmonids about $60 \%$ and scombrids as high as $70 \%$ muscle content of body weight. As is generally known, higher the- muscle content in fish greater is the demand for it in the market even though taste does play a crucial role. However, it is not just the muscle portion alone that is edible in fish. There are other organs/tissues which are also edible. For instance, liver, gonad etc., depending on their size. Skin, however, is usually consumed along with the underlying muscle tissue after the removal of scales.

Thus, in the present study, even if liver and gonad tissues are discarded along with the other visceral organs, as inedible (as often is the case mostly on account of their small size) the edible portion (muscle tissue plus the overlying adhering skin) in immature fish, yet, amounts to an impressive $56.49 \%$, while in mature male and female the values of edible portion are $61.92 \%$ and $53.29 \%$ respectively. Thus, it may be stated that E.suratensis is a meaty fish whose edible portion showing variation with the size of fish and hence, the maturity condition.

The high proportion of edible body parts in mature male compared to female may be due to the higher portion of visceral organs in female $(6.91 \%)$ than in male $(3.96 \%)$. Miller (1974) reported a value of $47.9 \%$ dress-out weight for Sarotherodon hornorum and 5.3\% for S. mossambicus. Edwardson (1976) found out the edible portion (filleted) of S.mossambicus to be at $38 \%$. According to Hickling (1963) the edible portion of S.mossambicus varied with the size of the fish and accordingly fish weighing $450 \mathrm{~g}, 700 \mathrm{~g}$ and $2000 \mathrm{~g}$ yielded $24 \%, 27 \%$ and $46 \%$ of its body weight as edible portion indicating that bigger the fish higher the proportion of edible parts in fish. Edwardson (1976) reported that carp had $53 \%$ and trout $70 \%$ of its body weight as edible portion. The calorific content of the entire animal is an important variable to be determined in energy flow studies, for its knowledge makes it possible to express dry weights in terms of energy units. Hence, much effort has been made earlier to measurethe calorific content of the diet and tissues of many organisms (Slobodkin and Richman, 1961; Paine and Vadas, 1969; Cummins and Wuycheck, 1971 and Jobling, 1995).

Biochemical constituents of animals are known to vary with seasons, size of animals, stage of maturity and the availability of food. These in turn affect the caloric content of the animal (Wootton, 1974; Wootton and Evans. 1976; Wootton1979; Hunter and Long, 1981). Jobling,(1995) reported that a deposition of 19 lipid $(38 \mathrm{~kJ})$ leads to a weight increase of $1 \mathrm{~g}$, whereas deposition of 19 protein $(24 \mathrm{~kJ})$ also leads to the deposition of $3-4 \mathrm{~g}$ water. Therefore, changes in weight alone may not always give an accurate reflection of growth in terms of energy gain. Hence, estimation of energy values of fish body can provide the accurate nutritional status offish.

The distribution / contribution of energy in different body parts of E. suratensis showed that muscle tissue contained the maximum energy compared to other body parts. Evidently this must be due to the fact that nutrient rich muscle tissue comprise more than $50 \%$ of the body weight of fish. 
Table.1 Proportion of edible and inedible body parts and their energy profile in Etroplus susratensis

\begin{tabular}{|c|c|c|c|c|c|c|c|c|c|c|c|c|c|c|c|}
\hline \multirow{2}{*}{$\begin{array}{l}\text { Maturity } \\
\text { stages }\end{array}$} & \multirow[t]{2}{*}{ Parameters } & \multicolumn{10}{|c|}{ INEDIBLE PORTION } & \multicolumn{3}{|c|}{ EDIBLE PORTION } & \multirow[t]{2}{*}{ WHOLE } \\
\hline & & Head & $\begin{array}{l}\text { Pectoral } \\
\text { fins }\end{array}$ & $\begin{array}{l}\text { Pelvic } \\
\text { fins }\end{array}$ & $\begin{array}{l}\text { Dorsal } \\
\text { fins }\end{array}$ & $\begin{array}{l}\text { Anal } \\
\text { fins }\end{array}$ & $\begin{array}{l}\text { Caudal } \\
\text { fins }\end{array}$ & Scales & $\begin{array}{l}\text { Visceral } \\
\text { organs }\end{array}$ & $\begin{array}{l}\text { Vertebral } \\
\text { column }\end{array}$ & $\begin{array}{l}\text { Total } \\
\text { inedible }\end{array}$ & $\begin{array}{l}\text { Muscle(free } \\
\text { of bones) }\end{array}$ & Skin & $\begin{array}{l}\text { Total } \\
\text { edible }\end{array}$ & \\
\hline \multirow[t]{3}{*}{ Immature } & $\begin{array}{l}\text { Wet } \\
\text { weight(g) }\end{array}$ & 3.7 & 0.06 & 0.03 & 0.21 & 0.1 & 0.1 & 0.27 & 1.6 & 0.5 & 6.57 & 7.19 & 1.34 & 8.53 & 15.1 \\
\hline & $\begin{array}{l}\text { Percent } \\
\text { body wet } \\
\text { weight (\%) }\end{array}$ & 24.5 & 0.4 & 0.2 & 1.39 & 0.66 & 0.66 & 1.79 & 10.6 & 3.31 & 43.51 & 47.62 & 8.87 & 56.49 & -- \\
\hline & $\begin{array}{l}\text { Energy } \\
\text { content(kJ/g } \\
\text { dry wt.) }\end{array}$ & 17.47 & - & 0 & $11.24 *$ & - & - & 17.47 & 16.43 & - & 15.65 & 19.55 & 15.9 & 17.47 & 18 \\
\hline \multirow[t]{3}{*}{$\begin{array}{l}\text { Mature } \\
\text { Female }\end{array}$} & $\begin{array}{l}\text { Wet weigh } \\
t(g)\end{array}$ & 35.73 & 0.87 & 0.8 & 3.66 & 3 & 2.2 & 8.13 & 10.17 & 4.17 & 68.73 & 69.3 & 9.13 & 78.43 & 147.17 \\
\hline & $\begin{array}{l}\text { Percent } \\
\text { body wet } \\
\text { weight }(\%)\end{array}$ & 24.28 & 0.59 & 0.54 & 2.49 & 2.04 & 1.5 & 5.52 & 6.91 & 2.83 & 46.7 & 47.09 & 6.2 & 53.29 & -- \\
\hline & $\begin{array}{l}\text { Energy } \\
\text { content }(\mathrm{kJ} / \mathrm{g} \\
\text { dry wt.) }\end{array}$ & 18.68 & - & - & $12.80 *$ & - & - & 12.28 & 26.21 & -- & 17.49 & 20.59 & 19.81 & 20.2 & 18.73 \\
\hline \multirow[t]{3}{*}{$\begin{array}{l}\text { Mature } \\
\text { Male }\end{array}$} & $\begin{array}{l}\text { Wet weigh } \\
\mathrm{t}(\mathrm{g})\end{array}$ & 30.93 & 0.7 & 9.07 & 3.8 & 2.07 & 2.27 & 8.07 & 6.17 & 4.35 & 59.43 & 86.33 & 10.27 & 96.6 & 156 \\
\hline & $\begin{array}{l}\text { Percent } \\
\text { body wet } \\
\text { weight }(\%)\end{array}$ & 19.83 & 0.44 & 0.69 & 2.44 & 1.33 & 1.44 & 5.17 & 3.96 & 2.79 & 38.09 & 55.34 & 6.58 & 61.92 & -- \\
\hline & $\begin{array}{l}\text { Energy } \\
\text { content(kJ/g } \\
\text { dry wt.) }\end{array}$ & 16.49 & - & - & $12.28 *$ & - & - & 12.8 & 24.91 & -- & 16.62 & 19.5 & 19.79 & 19.65 & 17.75 \\
\hline
\end{tabular}


Table.2 Energy distribution pattern (\%) in different body parts of E.suratensis

\begin{tabular}{|c|c|c|c|c|c|c|}
\hline $\begin{array}{l}\text { Body parts of the } \\
\text { fish }\end{array}$ & $\begin{array}{l}\text { Wet weight } \\
\text { (g) }\end{array}$ & $\begin{array}{c}\text { Moisture } \\
(\%)\end{array}$ & $\begin{array}{l}\text { Dry matter } \\
(\mathrm{g})\end{array}$ & $\begin{array}{c}\text { Energy density } \\
\text { (kJ/ g dry } \\
\text { matter) }\end{array}$ & $\begin{array}{c}\text { Total } \\
\text { energy }(\mathbf{k J})\end{array}$ & $\begin{array}{l}\text { \% of energy } \\
\text { distribution }\end{array}$ \\
\hline \multicolumn{7}{|c|}{ Immature } \\
\hline Head & 3.91 & 73.51 & 1.03 & 17.47 & 17.99 & 24.99 \\
\hline Fins & 0.529 & 47.44 & 0.28 & 11.24 & 3.15 & 4.38 \\
\hline Scales & 0.303 & 35.20 & 0.19 & 17.47 & 3.32 & 4.61 \\
\hline Skin & 1.481 & 67.70 & 0.48 & 15.39 & 7.39 & 10.27 \\
\hline $\begin{array}{l}\text { Visceral } \\
\text { organs }\end{array}$ & 1.807 & 70.56 & 0.53 & 16.43 & 8.71 & 12.10 \\
\hline Muscles & 7.62 & 79.25 & 1.58 & 19.55 & 31.41 & 43.64 \\
\hline \multicolumn{7}{|c|}{ Mature- Females } \\
\hline Head & 52.00 & 68.81 & 16.22 & 18.68 & 302.99 & 31.84 \\
\hline Fins & 15.80 & 53.73 & 7.31 & 12.80 & 93.57 & 9.83 \\
\hline Scales & 12.40 & 68.75 & 3.88 & 12.88 & 47.65 & 5.00 \\
\hline Skin & 11.60 & 74.62 & 2.74 & 19.81 & 58.24 & 6.12 \\
\hline Visceral organs & 10.00 & 75.99 & 2.40 & 26.21 & 62.90 & 6.61 \\
\hline Muscles & 93.00 & 79.83 & 18.76 & 20.59 & 386.27 & 40.59 \\
\hline \multicolumn{7}{|c|}{ Mature- Females } \\
\hline Head & 32.80 & 66.04 & 11.14 & 16.49 & 183.70 & 24.43 \\
\hline Fins & 8.00 & 49.64 & 4.03 & 12.28 & 49.49 & 6.58 \\
\hline Scales & 7.00 & 57.73 & 2.96 & 12.80 & 37.89 & 5.04 \\
\hline Skin & 12.20 & 69.93 & 3.67 & 19.79 & 72.63 & 9.66 \\
\hline $\begin{array}{l}\text { Visceral } \\
\text { organs }\end{array}$ & 5.50 & 77.46 & 1.24 & 24.91 & 30.89 & 4.11 \\
\hline Muscles & 85.90 & 77.47 & 19.35 & 19.50 & 377.33 & 50.18 \\
\hline
\end{tabular}

The second highest energy containing organ is the head which may be attributed to the higher biochemical composition compared to other parts such as fins, scales, skin and visceral organs.

There is paucity of information on bioenergetic studies of Indian fish species. As far as the energy density of edible and inedible parts of E. suratensis are concerned immature fish registered a mean value of $17.47 \mathrm{~kJ} / \mathrm{g}$ in edible parts and $15.65 \mathrm{~kJ} / \mathrm{g}$ in inedible parts as against $17.49 \mathrm{~kJ} / \mathrm{g}$ and $18.73 \mathrm{~kJ} / \mathrm{g}$ in mature female and $19.65 \mathrm{~kJ} / \mathrm{g}$ and $16.62 \mathrm{~kJ} / \mathrm{g}$ in mature male respectively.
The lower energy value in inedible body parts of immature fish may be due to the lower energy content of visceral organs probably due to the less developed gonad and liver tissues. In contrast, the energy values of inedible body parts of mature fish were high $(26.21 \mathrm{~kJ} / \mathrm{g}$ in female and $24.91 \mathrm{~kJ} / \mathrm{g}$ in male) possibly due to the well developed gonad and other organs of high energy value for example liver $(27.37 \mathrm{~kJ} / \mathrm{g}$ each in both sexes) and ovary $(21.80 \mathrm{~kJ} / \mathrm{g})$.

Pigott and Tucker (1990) reported that a lowfat white fish contains about $80 \mathrm{kcal}$ per $100 \mathrm{~g}$ edible portion (raw), medium fat about 100 
$\mathrm{kcal} / 100 \mathrm{~g}$ and high fat fish between 150 to $225 \mathrm{kcal}$ II $00 \mathrm{~g}$ ( 1 calorie $=4.184 \mathrm{~J})$. In the present study, a mature E. suratensis is found to contain a very low fat and high protein content Therefore, it may be considered as an ideal low calorie and protein rich source of food. Wootton (1979) has calculated a mean value of ripe ovaries of 50 teleost species at $23.48 \mathrm{~kJ} / \mathrm{g}$ dry weight. In the present study also, ripe ovaries of pearl spot have been found to contain almost similar value (21.80 $\mathrm{kJ} / \mathrm{g}$ dry matter).

The head of pearl spot contained considerable energy ranging from $17.47 \mathrm{~kJ} / \mathrm{g}$ in immature to $18.68 \mathrm{~kJ} / \mathrm{g}$ and $16.49 \mathrm{~kJ} / \mathrm{g}$ in mature female and male respectively. Similarly, other parts of inedible portion also contain considerable energy in them which may be effectively used in feed formulation / manure preparation.

\section{References}

Cummins, K. W. and. Wuycheck, J. C.( 1971) Caloric equivalents for investigations in ecological energetics. Mitt. int. Ver. Limnol. 18: $158 \mathrm{p}$

Edwardson W (1976). Energy demands of aquaculture: A world wide survey. Fish farming International 3(4):10-13

Hickling CF (1963). The cultivation of Tilapia. Scientist America. 208(5): 143148, 150-152.

Hora, S.L. and. Pillay T.V.R, : Handbook on fish culture in the Indo-Pacific region. FAO Fish. Biol.Tech.Pap., (1962), 14: 124.

Hunter, J.R., and Leong, R. (1981) The spawning energetics of female northern anchovy, Engruulis mordux. Fish. Bull.,
79:215-230.

Jayaprakash, V and Phil,M,1980. Culture possibilities of pearl spot Eutroplus suratensis in Kerala. Seafood Export Journal, Vol.12(11): 13-15.

Jobling, M. 1995. Environmental biology of fishes., Chapman \& Hall New York 455.

Joseph, M.M,: Brackish water finfish and shell fish resources of Karnataka In . Proceedings seminar on some aspects of Inland aquaculture in Karanataka, (1980), 17-26.

Paine, R. J. and R. L. Vadas 1969. Caloric values of benthic marine algae and theirpostulated relation to invertebrate food preference. Mar. Biol., Vol 4: 7986.

Pigott, G.M, Tucker, B.W. 1990. Seafood effects of technology on nutrition. MarcelDekker, Inc. New York.

Rattan, P.1994 Ecobiology of Pearl Spot (Etroplussuratensis Bloch) in. Goa Waters. Ph. D. Thesis Goa University

Slobodkin, L. B. and Richman,S.: 1961 Calories/gm in species of animals. Nature. 191, 299.

Wootton RJ, Evans GW (1976) Cost of eggproduction in three-spined stickleback (Gasterosteusaculeatus L.). J Fish Biol8:385-395

Wootton R J , 1974; The interspawning interval of three spinedstrickle back Gasterosteusaculeatus. J Zool., 173:331342

Wootton, R.J.,1979: . Energy costs of egg production and environmental determinants of fecundity in teleost fishes. Symp. Zool. Soc. Lond. 44:133159.

\section{How to cite this article:}

Shivaprakash, S. M. and N. Shivashankar. 2020. Distribution of Body Energy in Etroplus suratensis (bloch). Int.J.Curr.Microbiol.App.Sci. 9(01): 1282-1287.

doi: https://doi.org/10.20546/ijcmas.2020.901.141 